Notre Dame Law School

NDLScholarship

Journal Articles

Publications

2015

\title{
Grounding Human Rights in Natural Law
}

John M. Finnis

Notre Dame Law School, john.m.finnis.1@nd.edu

Follow this and additional works at: https://scholarship.law.nd.edu/law_faculty_scholarship

Part of the Human Rights Law Commons, and the Natural Law Commons

\section{Recommended Citation}

John M. Finnis, Grounding Human Rights in Natural Law, 60 Am. J. Juris. 199 (2015).

Available at: https://scholarship.law.nd.edu/law_faculty_scholarship/1257

This Article is brought to you for free and open access by the Publications at NDLScholarship. It has been accepted for inclusion in Journal Articles by an authorized administrator of NDLScholarship. For more information, please contact lawdr@nd.edu. 


\section{HEINONLINE}

Citation: 60 Am. J. Juris. 1992015

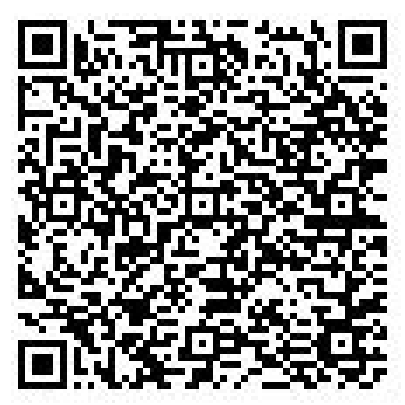

Content downloaded/printed from HeinOnline

Thu Sep 29 10:53:21 2016

-- Your use of this HeinOnline PDF indicates your acceptance of HeinOnline's Terms and Conditions of the license agreement available at http://heinonline.org/HOL/License

-- The search text of this PDF is generated from uncorrected OCR text.

-- To obtain permission to use this article beyond the scope of your HeinOnline license, please use:

\section{Copyright Information}




\title{
Grounding Human Rights in Natural Law
}

\author{
John Finnis ${ }^{1}$
}

\begin{abstract}
Of the published reviews of Natural Law and Natural Rights, one of the most, and most enduringly, influential was Ernest Fortin's review-article "The New Rights Theory and the Natural Law" (1982). The present essay takes the occasion of that review's latest republication to respond to its main criticisms of the theory of natural law and natural or human rights that is articulated in Natural Law and Natural Rights. The response deals with a number of fundamental or strategically important issues: the freedom of thought and/or the intellectual autonomy and integrity of work within an intellectual tradition that overlaps with a "faith tradition"; the hierarchies among the basic human goods; the place of virtue in the book, and the relation between rights and freedom, and rights and virtue; the unsoundness of the Straussian bifurcation between natural right and natural rights; whether natural law is only analogically law, and the relation between moral law and sanctions; and the possibility of true exceptionless negative moral precepts.
\end{abstract}

Keywords: Natural Law, Natural Rights, Aquinas

\section{Purposes, Predicament, Method, and the "Art of Writing"}

Natural Law and Natural Rights ${ }^{2}$ [NLNR] says nothing about rights until the eighth of its thirteen chapters. By then, it has taken up (i) the methodology of social (including political) science, and (ii) the errors of many early modern and contemporary thinkers about natural law theory and about their own traditions. It has (iii) teased out and (iv) elaborated the first principles of practical thinking and deliberating, and then (v) the foundational moral principles that resolve, in principle, the problem that our choices must be made-and should be made

${ }^{1}$ Biolchini Family Professor of Law, University of Notre Dame; Professor of Law and Legal Philosophy Emeritus, University of Oxford. Email: john.finnis@law.ox.ac.uk. This essay was occasioned by the invitation of Daniel Philport and Ryan Anderson - as editors of a volume (to be published in 2016 by the University of Notre Dame Press) republishing essays on Catholic political thought that were first published in The Review of Politics - to contribute a response (the only essay written for the volume) to Ernest Fortin, "The New Rights Theory and the Natural Law," The Review of Politics 44 (1982): 590-612. The version to be published in their volume will be supplemented by some extracts from a draft response to Fortin that I began and discontinued in 1982/3. Fortin's review-essay is already republished in J. Brian Benestad, Ernest Fortin: Collected Essays, vol. 2, Classical Christianity and the Political Order: Reflections on the Theologico-Political Problem (Lanham, MD: Rowman \& Littlefield, 1996), 265-86, but bracketed page references to it below are to the Review of Politics version cited above.

2 John Finnis, Natural Law and Natural Rights (Oxford: Oxford University Press, 1980; 2 d edition with identical pagination and a 65-page Postscript, 2011). 
reasonably-among multiple intrinsically valuable and intelligible goods all actualizable in the lives of many human persons. The book then considers (vi) the fundamental types of human association and community, the intelligibility, goodness and centrality of common good in family, voluntary and civic associations, and in political communities. It reviews (vii) the forms of justice, the principles that give that supreme inter-personal virtue specificity by identifying how the demands of the supreme moral virtue-practical reasonableness or prudentiabear on conduct or inaction that affects other persons. Only after all this does $N L N R$ consider (viii) rights. They are shown to be simply the entailments of the virtue of justice, the correlatives of duties of justice-not as mere shadows of those duties but as, in a way, their point.

There follow chapters on (ix) authority, on (x) law as the politically desirable standard form of authority, on (xi) obligations in morality and law as the requirements of acting for common good, on (xii) the reality and nullity of unjust laws, and on (xiii) the need for, and availability of, a meaningful philosophical response to questions about the ultimate origins and sense of all these intelligibilities. Each of the thirteen chapters, like the whole venture of displaying their mutually supportive explanatory and practical force in personal and political life, has the purpose of making available to young, secular students the main truths of the classical tradition in political philosophy. The principal bearers of that tradition, for many centuries, have been thinkers who also accepted the truth of Christian revelation as transmitted in Catholic doctrine and theological reflection. Most of the book's readers could be expected to approach it with assumptions widely and deeply opposed to that doctrine and theology. Every part of NLNR is shaped and marked by consciousness of that challenging fact.

It was written during the very years of what Ernest Fortin justly called "the pseudomorphic collapse of Neo-Thomism in the wake of Vatican II."3 I shared Fortin's judgment that the neo-Thomism current in manuals and textbooks in the decades before 1965 was philosophically inauthentic. Anyone embarking on a project such as $N L N R$ needed to investigate, as a top priority, whether Aquinas and Aristotle were guilty of the fallacies and elisions of neo-Thomism, and if they were not, whether a philosophically critical and free-standing exposition of the foundations of ethics and political philosophy would show that, in their main lines, Aquinas and Aristotle had got there first, so to speak, and can, now too, be philosophically helpful. The work of recovering the real theses and argumentation of, particularly, Aquinas had been pursued in the late 1950s and the 1960s by French-speaking Dominicans such as P.M. Van Overbeke and P.-D. Dognin,${ }^{4}$ and

${ }^{3}$ Ernest Fortin, "The Trouble with Catholic Social Thought" (1988) in J. Brian Benestad, Ernest Fortin: Collected Essays, vol. 3, Human Rights, Virtue, and the Common Good: Untimely Meditations on Religion and Politics (Lanham, MD: Rowman \& Littlefield, 1996), 311. A pseudomorphic crystalline is one that assumes the shape of another mineral that it has replaced; I take it that Fortin's phrase predicates (by hysteron proteron) pseudomorphism of Neo-Thomism rather than of its collapse (which was real enough, sociologically speaking). On the inauthenticity (pseudomorphism) of the "neo-Suarezian theory... widespread in Catholic seminaries until the 1960s," see NLNR, 49; also 47.

${ }^{4}$ See $N L N R, 228$. 
then, with decisive clarity, by Germain Grisez. ${ }^{5}$ The testing of Aquinas's theses in dialectic with Hume and with the main academic British moral philosophers of the twentieth century, during the gestation of $N L N R$, can in part be traced in essays of the 1970s published first or republished in Collected Essays of John Finnis (2011). ${ }^{6}$

$N L N R$ is written primarily for law students, undergraduate and graduate, ${ }^{7}$ and for lecturers and other teachers many of whom have little acquaintance with, and no predisposition to favor, the philosophical and theological tradition in which the term "natural law" finds its origins and its home. These are the readers whom the book seeks to meet where they are. Few indeed, however, were the reviewers who noticed, or made even the slightest allowance for, the book's genre, its rhetorical predicament, and its strategies, its "art of writing."

I hoped that, for example, my giving common good and justice priority over rights would signal to thinkers interested in and aware of the tradition of political thought that the book and its author stood in opposition to some main prejudices of modernity. That scholars who thought of themselves as guardians of the tradition, or of classical wisdom, would turn out to be readers whose comprehension was blocked by questionable presuppositions - as far-reaching, or nearly so, as the errors and oversights of those who think of themselves as moderns-was something I did not really envisage. Nor did I really envisage that scholars who thought of themselves as sensitive to "the art of writing" in oppressive circumstances would turn out to be inattentive to the book's rhetorical and structural precautions for disarming or circumventing the hostility with which many modern readers approach anything associated by them with the past, especially the past of Christianity and of all that ante-dates the secular "liberalisms" and conventional radicalisms of 1980 and today.

The long review of NLNR by Ernest Fortin in 1982 showed up these mistaken hopes of mine, and my failures of foresight, with special clarity. The review has had considerable influence over the subsequent thirty years, and the present essay is a belated but still perhaps timely response.

Writing $N L N R$, as now, I judged that the divine revelation constitutive of Christianity - the central form of which (as the book's index discreetly indicates) must be Catholicism-is the central event of human history and became the bearer of what is sound in the philosophical tradition of moral and political (and therefore legal) philosophy inaugurated, masterfully, by Plato and

\footnotetext{
${ }^{5}$ Germain Grisez, Contraception and the Natural Law (Milwaukee, WI: Bruce, 1964); "The First Principle of Practical Reason: A Commentary on the Summa Theologiae, 1-2, Question 94, Article 2," Natural Law Forum 10 (1965): 168-96.

65 volumes (Oxford: Oxford University Press, 2011), hereafter CEJF. See especially CEJFI (Reason in Action), essays 6 (1970), 7 (1971), 8 (1975); in CEJFIII (Human Rights and Common Good), essays 3 and 18 (1973), 11 (1972); in CEJF IV (Philosophy of Law), essay 18 (1972); and CEJFV (Religion and Public Reasons), essay 7 (1973); and there were others, notably "Natural Law in Humanae vitae," Law Quarterly Review 84 (1968): 465-71; and "Natural Law and Unnatural Acts," Heythrop Journal 11 (1970): 365-87.

7 But H.L.A. Hart, who had commissioned it and specified its title, said a touch gloomily, after a first reading of the typescript, that it would appeal more to philosophers.
} 
Aristotle. ${ }^{8}$ And I thought also that the moral and political philosophy shaped by Hobbes, Locke, Hume, Bentham and their successors down to today is a series of blunders and oversights, partly but inadequately identified, and then inadequately resisted, by Kant and his successors, and partly prepared for by deficiencies in the (neo-)scholasticism of Aquinas's sixteenth-century and later successors.

Fortin seems not to have noticed the book's own statement of its program. As the preliminary Part I draws towards its close, and after more than a page expounding the errors of Gabriel Vazquez, Francisco Suarez, and later neo-scholastics about obligation, errors occasioned by their departures from Aquinas's thought, and by neglect of ends and goods, NLNR says:

The reader will ask how Aquinas explained the difference between moral thinking and merely prudential reasoning (in the modern sense of 'prudential'), and how he accounted for the peculiarly conclusory sense of the moral 'ought'. The answer must be that Aquinas's account of these matters is, at best, highly elliptical, scattered, and difficult to grasp, and at worst, seriously underdeveloped; and that these deficiencies occasioned the unsatisfactory responses of those who professed to follow him in the later history of philosophical theology. But to this I must add that the materials for a satisfactory development of the sort of position espoused by Aquinas are available, and that the attempt to put these materials to use is encouraged by the impasse in which the sixteenth- and seventeenth-century theories of natural law manifestly found themselves. The subsequent chapters of this book incorporate such an attempt.

... the reason for making the attempt is that a theory of practical reasonableness, of basic forms of human good, and of practical principles, such as the theory Aquinas adumbrated but left insufficiently elaborated, is untouched by the objections which Hume (and after him the whole Enlightenment and post-Enlightenment current of ethics) was able to raise against the tradition of rationalism eked out by voluntarism.?

${ }^{8}$ See e.g. "Catholic Positions in Liberal Debates," (1999), essay 6 in CEJFV, Religion and Public Reasons, 118. It is widely assumed that to hold such an opinion is to render oneself unfit for genuine philosophical enquiry and argument, and is to make one little more than an apologist for doctrine and theology. But the assumption cannot be explicated or defended without resort, covert if not overt, to the premise that Catholicism is false. For if Catholicism is substantially true, then a Catholic scholar can pursue philosophical, scientific or historical inquiries and discussions with full freedom of mind-as many have done and do-confident that when pursued with such resolute freedom and diligence their findings and results will not conflict with Catholic doctrine and, where their subjectmatter overlaps with Carholic doctrine, will turn out to be clarified and, if possible, made more certain by the additional information conveyed by the divine revelation embodied in that doctrine. $N L N R$ does not proclaim this, but tacitly proceeds on this basis.

9 NLNR, 46-7 (emphases added). The passage continues:

\begin{abstract}
That tradition presented itself as the classical or central tradition of natural law theorizing, but in truth it was peculiar to late scholasticism. It was attractive to non-Catholics (like Grotius, Culverwel, and Clarke) who adopted its major concepts not least because of its strong verbal and conceptual resemblances to the Stoicism (XIII.1) so much admired in European culture from the Renaissance to the end of the eighteenth century. The substantive differences between the theory of natural law espoused by Vazquez and Suarez (and most Catholic manuals until the other day) and the theory espoused by Aquinas are scarcely less significant and extensive than the better-known differences between Aristotelian and Stoic ethics.
\end{abstract}

The section ends with a series of far-reaching critical remarks about ethical and meta-ethical positions characteristic of the period from 1630 to today, in which Aquinas is presented as the primary critic, and as one who quite obviously speaks for the book's author. 
$N L N R$ thus defined itself as an attempt to develop Aquinas's theory, so as to give an account of natural law that is philosophically sound, untouched by Humean and all subsequent philosophical and cultural objections, and at the same timeto the extent permitted by philosophically critical criteria-is more authentically in line with St. Thomas's thought than were his most influential sixteenth-century commentators and followers.

The book's prominent statements ${ }^{10}$ that it is not deferring to the authority of Aquinas, or proceeding out of reverence for him (or of Catholic doctrine), are sincere and true. They are also rhetorically strategic, because countless readers will approach the book with the Protestant and secularist assumption that a Roman Catholic is a mental slave, and a Thomist abjectly so. The assumption is fallacious, a petitio principii, a vicious circle, in so far as it covertly or overtly assumes that Catholicism and Thomism are false or substantially erroneous. For that is the very question in issue in the work of Thomists. ${ }^{11}$ If Thomism turns out to be substantially correct by the autonomous criteria of critical, free-thinking philosophy, a good working method in philosophizing is to start with Thomas's positions and test them as rigorously as one can against those autonomous criteria and against the most careful and stringent criticisms that one can find in the literature or devise in one's reflection. ${ }^{12}$ If the assumption of Thomists' mental servitude is to be held non-fallaciously, it must be accompanied by a willingness to consider the possibility that Thomist positions in philosophy are true, and are reachable by autonomous critical reflection; testing that possibility will then be a kind of joining in the enterprise of Thomists, albeit without the initial presumption that this investigation will be fruitful in attaining substantive philosophical truths about reality and value. Then, as investigation confirms the plausibility of Thomist positions, especially when considered not one by one but as a network, though always also against the evidence of experience, history and logic, one's initial presumption of Thomism's falsehood withers away and one can start to hold the contrary presumption that it is a generally sound guide to truthattaining positions in philosophy. So none of this need proceed from reverence for Aquinas, or out of deference to his (or the Catholic Church's) authority. Hence the book's disclaimers, which are fully compatible with its method.

What is that method? As is easily noticed by careful readers, especially if they attend to the argument of chapter II and the endnotes to chapters III and IV (or subsequent chapters), the book treats its own theses as also Aquinas's (and vice versa) except when it specifically asserts some deficiency in the latter-a deficiency

${ }^{10}$ See $N L N R$, vi, 46.

11 I call persons "Thomists" if they regularly agree with positions of St. Thomas himself, and work with a presumption that Aquinas is much more likely to be sound than mistaken. Such a person would be well advised not to accord the same presumption to the works of other Thomists, still less to the works of neo-scholastics, many of whom adopted, consciously or not, philosophical positions at odds with Aquinas. I call positions "Thomist" if they are positions of Aquinas himself, taken as a coherent whole, not simply statement by statement; such a whole I call "Thomism".

12 The testing should not take positions in isolation, but as parts of a much wider network of Thomist positions, all of which are implicitly in issue in the testing of any one of them-for similarly, critical objections, though they sincerely and reasonably present themselves as particular, in fact presuppose a network of supportive presuppositions, all of which are thus implicitly in issue. 
or flaw that almost invariably is not error on his part but unclarity or some other form of incompleteness in the provision of premises. Such readersespecially those properly attentive to "the art of writing"-soon judge that the book is treating Aquinas's views as warranted (and true) save when it specifically says otherwise. Fortin's reading is faulty exegesis in so far as it sees only "numerous references to [Aquinas] in the text" [592]. Indeed, the lead-up to that remark is severely mistaken about all the four authors mentioned:

"[Finnis's] own method of procedure is largely deductive in character and resembles that of Rawls and H.L.A. Hart more than it does that of Thomas Aquinas, despite numerous references to him in the text" [592].

In truth, the book scorns Rawls's ${ }^{13}$ and Hart's ${ }^{14}$ methods (widely different from each other!) of dealing with the foundations of ethics (and thus of political and legal theory), especially for their theories about human good(s). It equally disdains the foundationless and unwarranted character of their principal theses in ethics, politics and jurisprudence.

Nor can the book's method of identifying basic human goods and the main requirements of practical reason be reasonably said to be deductive. It does not "lay down as self-evident" the basic pre-moral values (basic human goods), but resorts to a variety of encouragements to readers to re-enact for themselves, reflectively, the process-called by Aristotle, Aquinas and thus by the book inductive $e^{15}$-by which they attained some insight into those basic goods. Every reader,

${ }^{13}$ Against Rawls's method and theory: NLNR, 76 (the first sentence quotes Rawls, the second is a root-and-branch rejection of his foundational assumption and method); 82 (Rawls's "primary goods" are not basic human goods); 106 (we must not use Rawls's theory of "thin theory of the good" or his would-be "democratic" but in fact arbitrary "impartiality between differing conceptions of human good," his "radical emaciation of human good"); 109 (Rawls disregards the second requirement of practical reasonableness, and his basic position about selection of principles in the Original Position is made worthless by an elementary logical fallacy); 130 (ditto); 157 (Rawls's view of the "shared final end" of members of a sociery is mistaken); 163 (a theory of justice should not be restricted, as Rawls's is, to the basic institutions of society); 164 (nor should a theory of justice be restricted, as Rawls's is, to a society whose members are fully compliant with the principles of justice); 293 (erroneous social engineering and social control theories of law are in the spirit of Rawls's "thin theory of the good"); and now 453 (the critiques on 108-9 go to the heart of $A$ Theory of Justice and should be extended to his Political Liberalism). Alongside these multiple rejections of Rawls's main views are three or four favorable references are to quite minor aspects of his theory and method. For my very considered but dismissive 1973 review of $A$ Theory of Justice, see CEJF III, essay 3 (pp. 72-5).

${ }^{14}$ Against Hart's ethical method and theory of "the minimum content of natural law": NLNR, 30-1 (against Hart's claim that "the good for man" is all debatable); 52-3 (against Hart's depiction of the teleological view of nature); 82 (against Hart's confusion between basic values and the material conditions for pursuing them, and against his reduction of basic goods to one, survival [and whose? of what?]); 163 (against Hart's restriction of the principles of justice to "treat like cases alike, different cases differently'); 227 (against Hart's preference for a "choice" theory of rights).

${ }^{15} N L N R, 77$ (commenting on the character of the book's account of first principles of practical reason):

Aquinas followed Aristotle's theory of 'induction' of indemonstrable first principles by insight working on observation, memory, and experience, but extended the account to a parallel 'induction' of indemonstrable first principles of practical reason (i.e. of natural law) by insight working on felt inclinations and a knowledge of possibilities: S.T. I-II q. 94 a. 2 (first principles, naturally known, of natural law)... I-II q. 10 a. 1c; II-II q. 47 a. 6c; II-II q. 79 a. 2 ad 2; In 2 Sent. d. 24, q. 2 a. 3 (for any definite knowledge of first principles we need both sense-experience and memory). 
Fortin included, certainly did once (good by good), when young, attain such insights, and also began to deploy them with more, or less, adequate coherence and integrity as - when thus taken in combination with each other and as goods realizable in the lives of others as well as oneself-morally as well as pragmatically significant guides to decision making. No one who seriously reflects upon the lines of thought developed at chapter length (chap. III) about the good of knowledge, and upon the argumentation (III.6) on the dialectical defensibility but radically basic character of our knowledge of that good's goodness, will call this a "laying down" of anything. The same goes for chapter IV's identification of other basic goods/values. And chapter V, like the rest of the book, plainly denies Fortin's claim that $N L N R$ presents "the universal norms of private and public morality" as reached "by way of entailment" from the premoral basic values/ goods. ${ }^{16}$ For: between the basic goods and any norms of morality stand, as new premises, the "methodological requirements of practical reasonableness," attained by another but quite different kind of induction (or abduction). ${ }^{17}$ No deduction or entailments here, nor indeed much "quasi-mathematical rigor" [593], meritorious or otherwise. Instead, an itemization of aspects of deliberation and choice that philosophers have reflectively identified as pre-eminently important elements of reasonableness in action.

\section{The Governing Natural Virtues: Practical Reasonableness and Justice}

As NLNR repeatedly indicates, its key term "practical reasonableness" is intended to be understood as the precise counterpart and translation of phronēsis as that word appears in Plato and Aristotle, and of prudentia as used by Aquinas. Fortin claims [592] the term was first used by Joseph Raz, with whom I conducted seminars in Oxford for a quarter-century and more; I doubt the claim, and reject Fortin's assertion [597] that practical reasonableness bears only "a superficial resemblance to Aristotle's and Thomas's prudence." As for the word or phrase, I came up with it (so far as I remember) in reflection upon the common law

16 The only talk of entailment in the book's presentation of basic moral theory is at NLNR, 225, where it is said that the absolute human rights (pace Fortin [596], a small subset of human rights) are correlative to "the exceptionless duties entailed by [the seventh] requirement [of practical reasonableness] ... that it is always unreasonable to choose directly against any basic value, whether in oneself or in one's fellow human beings." Two entailments are mentioned here: the rights entailed by the duties and the duties by the seventh requirement. In the book's account of natural law, natural rights and moral and political theory, these-the only entailments asserted-occupy only a small part (albeit a very important one).

17 A year or two after $N L N R$-belatedly! - I reconceptualized these as implications of a master principle of openness to integral human fulfillment: Finnis, Fundamentals of Ethics (Oxford and Washington, DC: Oxford University Press and Georgetown University Press, 1983), 76. Behind this, again, was work by Grisez, and our joint work yielded Germain Grisez, Joseph Boyle and John Finnis, "Practical Principles, Moral Truth, and Ultimate Ends," American Journal of Jurisprudence 32 (1987): 99-151 (see especially 109, 112, 125-6, etc). See now NLNR, 419-20 (Postscript); and Joseph Boyle, "On the Most Fundamental Principle of Morality," in Reason, Morality, and Law: The Philosophy of John Finnis, ed. John Keown and Robert P. George (Oxford: Oxford University Press, 2013), 56-72, and my response at $473-5$. 
concept of the reasonable man, and upon the excessive grandeur of the common translators' term "practical wisdom" (for, say, Aristotle's phronessis). Be that as it may, this is $N L N R$ 's pivotal concept, and Fortin's misunderstandings of it pervade his review.

In the book, practical reasonableness is introduced as "the integrating good," the basic human good whose subject-matter or content is precisely the integration of the pursuit of any and all of the basic goods and corresponding practical principles. In the same breath, "the moral principles" are introduced as what are "involved in the pursuit" of this good of practical reasonableness. ${ }^{18}$ This is the basic human good that makes nonsense of Fortin's claims that the book's "pivotal thesis concern[s] the fundamental equality of all basic values." Having misunderstood the book's thesis that the basic goods are "all equally fundamental," Fortin converts it into a denial that there is "any natural hierarchy of ends," and concludes:

"It follows that the life of a great scholar, statesman, or religious leader is not intrinsically superior to that of a music buff, a valetudinarian, or a ski bum [602]."

But valetudinarians, by definition, are unreasonably concerned about their own health, and necessarily neglect the good of practical reasonableness. Ski bums are bums because, for the good of play, they shamefully neglect all other basic human goods, instrumentalizing the good of association to their self-centered purpose, and in constant violation, therefore, of the good of practical reasonableness too. Fortin's interpretation of chapter IV.4's remarks about the senses in which there is no single hierarchy of value among the basic goods simply sets aside the truly "pivotal thesis" on the opening page of chapter V. Headed "The good of practical reasonableness structures our pursuit of goods," that page states first that the multiplicity of basic goods, none instrumental or simply subordinate to the others in value, leaves us all with the questions "What is to be done? What may be done? What is not to be done?" It states next that to be free and responsible is to have choices such as between concentrating on (say) one value and commitment to others. And then it explains this responsibility:

For among the basic forms of good that we have no reason to leave out of account is the good of practical reasonableness, which is participated in precisely by shaping one's

${ }^{18} N L N R, 49$. The book's first reference to it is at p. 23:

What are principles of natural law? The sense that the phrase 'natural law' has in this book can be indicated in the following rather bald assertions, formulations which will seem perhaps empty or question-begging until explicated in Part Two. There is (i) a set of basic practical principles which indicate the basic forms of human flourishing as goods to be pursued and realized, and which are in one way or another used by everyone who considers what to do, however unsound his conclusions; and (ii) a set of basic methodological requirements of practical reasonableness (itself one of the basic forms of human flourishing) which distinguish sound from unsound practical thinking and which, when all brought to bear, provide the criteria for distinguishing between acts that (always or in particular circumstances) are reasonable-all-things-considered (and not merely relative-to-a-parricular purpose) and acts that are unreasonable-all-things-considered, i.e. berween ways of acting that are morally right or morally wrong - thus enabling one to formulate (iii) a set of general moral standards.

(emphases added). 
participation in the other basic goods, by guiding one's commitments, one's selection of projects, and what one does in carrying them out. ${ }^{19}$

And this is the point at which the book reaches, and reaches into, morality:

The principles that express the general ends of human life do not acquire what would nowadays be called a "moral" force until they are brought to bear upon definite ranges of project, disposition, or action, or upon particular projects, dispositions, or actions. How they are thus to be brought to bear is the problem for practical reasonableness. "Ethics," as classically conceived, is simply a recollectively and/or prospectively reflective expression of this problem and of the general lines of solutions which have been thought reasonable.

How does one tell that a decision is practically reasonable? This question is the subject-matter of the present chapter. ${ }^{20}$

Manifestly, then, the book treats the good of practical reasonableness as standing in a hierarchical relationship to all the other basic human goods. ${ }^{21}$ The book denies that the hierarchy is one of value. It impliedly asserts that the hierarchy is one of significance for, that is, importance in, making choices and commitments of every kind of generality, specificity or particularity.

Fortin seems not to have noticed that moral significance or importance might derive from something other than simple superiority in pre-moral value. That that importance is derived from something other is one of the book's most pivotal theses. The deeper understanding of Aquinas's ethics that I gained in writing Aquinas: Moral, Political, and Legal Theory (1998) only confirmed that for Aquinas, too, the bonum rationis, the good of practical reasonableness, is pivotal. ${ }^{22}$ This architectonic good is decisively important not because it ranks higher in goodness than life, knowledge, friendship, or love of God, but because of its inherent content: the goodness of pursuing intrinsic human goods in a reasonable way. And the classical synonym for that "in a reasonable way" is virtuously.

NLNR abstains, just as Fortin notices, from the classics' talk of virtue, virtues, and so forth. What he fails to notice is that the abstention is largely rhetorical, and that virtue dominates the book under another name, or pair of names. The first name is practical reasonableness. The equivalence of that with prudentia and phronesis is absolutely explicit, ${ }^{23}$ and as Fortin well knew, prudentia is the supreme

19 NLNR, 100 (emphases added).

${ }^{20} N L N R, 101$.

21 See also NLNR, 450:

"[T]here is no objective hierarchy amongst them" (p. 92). This proposition... would better have been: there is "no single, objective hierarchy" [thus Fundamentals of Ethics (1983), 51]. There are various hierarchies. Life is most necessary, as precondition for the others; transmission of life shares in that kind of necessity. As for pracrical reasonableness, its very intelligibility as a good is as being in charge of (and in that sense, above) the pursuit and realization of all the other basic goods.

22 John Finnis, Aquinas: Moral, Political, and Legal Theory (Oxford: Oxford University Press, 1998) [Aquinas], 83-5, 93, 98-9, 107-8, 119, 140, 225n. Most of these passages also state and verify its essential equivalence to the bonum virtutis, the good of virtue. See also CEJF I, 34, 176-7, 182-3.

${ }^{23}$ NLNR, 128: "the person who has phronesis, practical wisdom, full reasonableness (in the Latin writings, prudentia)."; 52: 
natural moral virtue that settles the shape and content of all other natural moral virtues, ${ }^{24}$ and is the only virtue that is both an intellectual and a moral virtue.

The other moral virtue to which the book gives elaborate attention (again, without using the word "virtue" or its cognates) is, of course, justice. In the classical schema of the cardinal virtues, it is next in strategic importance to prudentia. Fortin claimed that the book does not present justice as a virtue, that is, "as a disposition of the soul" [597]. But he was again entirely mistaken. According to $N L N R$ (not to mention Aquinas), ${ }^{25}$ all aspects of justice are particularizations of General Justice, and General Justice is defined as precisely a disposition of the soul; in the concluding, summarizing words of chapter VII.2: "Justice, as a quality of character, is in its general sense always a practical willingness to favour and foster the common good of one's communities, and the theory of justice is, in all its parts, the theory of what in outline is required for that common good." 26

The next-following section of chapter VII proceeds to show that realizing the common good involves (i) problems of distributing resources, opportunities, burdens of cooperation, etc., to particular individuals, and a (ii) range of other problems not involving common enterprises and dangers but responsibilities of one individual to another, such as duties of carefulness, duties of performing undertakings, and duties of compensation, etc. The guiding thought is that mere disposition to favor common good, in any of these ways, is not enough. Justice, as Aquinas observes, is not like courage and temperance, cardinal virtues measured by practical reasonableness's constitutional rule over passions of aversion and desire. ${ }^{27}$ Justice is about the right external action (or forbearance) in relation to other people, and justice is done even when it is done without good dispositions. So the measure of the virtue of justice is the right proportionality between one's actions (or abstentions) and the rights of the other; dispositions (the material of virtues) take second place in working out the theory of justice, and rightly

Aquinas, S.T. I-II q. 58 a. 4c, is very clear: no one can be morally upright withour (a) an understanding of the first principles of practical reasoning and (b) the practical reasonableness (prudentia) which brings those principles to bear, reasonably, on particular commitments, projects, actions...

102:

Each of these requirements concerns what one must do, or think, or be if one is to participate in the basic value of practical reasonableness. Someone who lives up to these requirements is thus Aristotle's phronimos and has Aquinas's prudentia; they are requirements of reasonableness or practical wisdom...

398: "Aquinas's account of prudentia, practical reasonableness."; see also 51, second note. ${ }^{24}$ See Aquinas, 84:

As Aquinas says, "all moral virtues involve a sharing in the good of practical reasonableness \{bonum prudentiae\}" [fn. II-II q. 53 a. 5 ad $1 \ldots$; III Sent. d. 36 a. Ic...; I-II q. 61 a. 3c...; [etc., etc.].

Also Aquinas, 104, 107n-8n, 119, 123-4 and texts of Aquinas there cited.

${ }^{25}$ Summa Theologiae [S.T.] II-II q. 58 a. 7; q. 61 a. 1; Aquinas, 133.

${ }^{26}$ NLNR, 165; S.T. II-II q. 58 a. 6c; Aquinas, 133.

27 S.T. II-II q. 58 a. 10. 
make no further appearance in $N L N R$ 's chapter on justice after the definition quoted above.

Quite generally, the problems of individual and communal moral life are not solved by talk about virtues. NLNR's terse explanation of its abstention from talk about virtue and virtues is on the page immediately following the page (just quoted from above) defining "Ethics" and the "moral' force" of the basic goods or general ends of human life. The explanation is implicit in the following:

How does one tell that a decision is practically reasonable? This question is the subjectmatter of the present chapter. The classical exponents of ethics (and of theories of natural law) were well aware of this problem of criteria and standards of judgment. They emphasize that an adequate response to that problem can be made only by one who has experience (both of human wants and passions and of the conditions of human life) and intelligence and a desire for reasonableness stronger than the desires that might overwhelm it. ${ }^{28}$

I interrupt to note Fortin's assertion that in NLNR "practical reasonableness... does not appear to be connected in any way with the inclinations of the appetite or dependent on them for the rectitude of its judgment" [597]. The lines just quoted contradict him, as is confirmed a few lines later when I say (about two specifically Aristotelean and Thomist articulations of the general interrelationship between right judgment and good character) "Such assertions can scarcely be denied." 29 But, as I go on to state,

they are scarcely helpful to those who are wondering whether their own view of what is to be done is a reasonable view or not. The notion of "the mean"... seems likewise to be accurate but not very helpful.... For what is "the mean and best, which is characteristic of virtue"? It is "to feel [anger, pity, appetite, etc.] when one ought to, and in relation to the objects and persons one ought to, and with the motives and in the manner that one ought to..." Have we no more determinate guide than this?

In the two millennia since Plato and Aristotle initiated formal inquiry into the content of practical reasonableness, philosophical reflection has identified a considerable number of requirements of method in practical reasoning. Each of these requirements has, indeed, been treated by some philosophers with exaggerated respect, as if it were the exclusive controlling and shaping requirement. For, as with the basic forms of good, each of these requirements is fundamental, underived, irreducible, and hence is capable when focused upon of seeming the most important.

Each of these requirements concerns what one must do, or think, or be if one is to participate in the basic value of practical reasonableness. Someone who lives up to these

${ }^{28} N L N R, 101$.

${ }^{29} N L N R, 102$. That the book associates itself with "the classical exponents of ethics" in their concern about experience of passions (and an inclination to practical reasonableness stronger than competing passions) is clear also from the endnote to that passage, at p. 128:

Elaboration of moral principles, and particular moral decisions, both require wisdom that is far from universal .... see, e.g., S. T. I-II q. 100 aa. 1, 3, 11; this wisdom is prudentia (S.T. II-II q. 47 a. $2 \mathrm{c}$ ad $1 ;$ aa. 6,15 ; and notes to II.3 above). On the folly of the many see S.T. I-II q. 9 a. 5 ad 3; q. 14 a. 1 ad 3 . On the corruption of practical reasonableness in various cultures and people(s), see S.T. I q. 113 a. 1; I-II q. 58 a. 5; q. 94 a. 4; q. 99 a. 2 ad 2; and II.3 above, and 225 n. 28 below. 
requirements is thus ${ }^{30}$ Aristote's phronimos and has Aquinas's prudentia; they are requirements of reasonableness or practical wisdom, and to fail to live up to them is irrational. ${ }^{31}$

The paragraph and section proceed for another couple of dozen lines, explaining why the resultant of these requirements is eudaimonia, that is, flourishing, and why these requirements of moral goodness are thus also requirements for fulfilling one's nature and of "natural law." NLNR's undertaking to its readers, in short, is to provide something more helpful as a guide to conscientious decision-making in individual and social life than a mere naming of relevant virtues and counseling a life of virtue, with reason ruling the passions but (as Fortin would have it) with rectitude of rational judgment dependent on "the inclinations of the appetite" 32 -advice easy enough to give but not much help to anyone, above all in the fields of social life and thus of justice (the book's fields).

In the 2011 Postscript to $N L N R$, there is a short preliminary section headed Virtues and Principles:

The book says little about virtue(s). That was deliberate, but it would have been appropriate to explain both the decision and the intrinsic relationship between virtues and principles, the priority of the latter, and the bearing of free choices' intransitive aspects (their lasting in the dispositions of the chooser) on the formation of virtues and vices. Aquinas, 124, explains why principles, propositional practical truths, are more fundamental than virtues, even than the master virtue of practical reasonableness (prudentia): 'for virtues are the various aspects of a stable and ready willingness to make good choices, and like everything in the will, are a response to reasons, and reasons are propositional'. ${ }^{33}$ And the relevant propositions are the first principles of practical reason(ing) (Chapters III and IV above) and the requirements of practical reasonableness (Chapter V), together with the more specific moral norms which result from bringing these two levels of principle to bear on one another. Some of this is hinted at in the paragraph on p. 102 above concerning Aristotle's idea of the 'mean' (virtue's mean between the vices of 'too much' and 'too little'-where reasons are the measure of the excessive and the fitting). But spelling out the inherent connection between principles and virtue(s), the logical and rational primacy of the former (a primacy acknowledged by Aquinas), ${ }^{34}$ and the grounds on which, nonetheless, Aquinas could judge it reasonable to arrange his largest discussion of morality under the various cardinal virtues, would have helped avoid the suspicion that 'virtue ethics' was or is an unexamined alternative to the kind of moral theory deployed in this book. It is not. ${ }^{35}$

That was said at large. But let me revert to Fortin's criticism, already adumbrated, that in $N L N R$ "the soul, its passions, and the reordering of those passions do not enter into account. Human beings may remain as they are as long as the institutions under which they live are as they ought to be" [397]. That is contradicted by

\footnotetext{
30 Note the equivalence indicated between the three terms by this "thus."

31 NLNR, 102, emphases adjusted.

32 Fortin, 597.

33 Finnis, Aquinas, 124; see also ibid., 187-8.

34 Aquinas, 124 nn.103, 104.

35 NLNR, 421-2.
} 
a passage which various readers have found pungent, pertinent, and suggestive of wider issues touching the soul and the ordering of its passions:

The fact is that human rights can only be securely enjoyed in certain sorts of milieu-a context or framework of mutual respect and trust and common understanding.... Consider, now, the concept of public morality, in its oddly restricted [conventional], sexual sense.... If it is the case that sexuality is a powerful force which only with some difficulty, and always precariously, can be integrated with other aspects of human personality and well-being-so that it enhances rather than destroys friendship and the care of children, for example; and if it is further the case that buman sexual psychology has a bias towards regarding other persons as bodily objects of desire and potential sexual release and gratification... then there is reason for fostering a milieu in which children can be brought up (and parents assisted rather than hindered in bringing them up) so that they are relatively free from inward subjection to an egoistic, impulsive, or depersonalized sexuality. Just what such a milieu concretely amounts to and requires for its maintenance is something that is matter for discussion and decision, elsewhere. But that this is an aspect of the common good, and fit matter for laws which limit the boundless exercise of certain rights, can hardly be doubted by anyone who attends to the facts of human psychology as they bear on the realization of basic human goods. ${ }^{36}$

The passage makes clear that the "milieu" or matrix in which human goods can be realized, harmed or destroyed includes the inner life, "psychology" in the sense that it can be affected for good or ill by cultural/educational encouragement to or discouragement from the self-discipline and virtue needed to integrate passions with reason and reasonable relationships, and so forth.

Fortin says that, in $N L N R$, "human beings may remain as they are." But the book's central section, on the specification of rights (to which I shall return below), states that

[t]here is, I think, no alternative but to hold in one's mind's eye some pattern, or range of patterns, of human character ... and then to choose such specification of rights as tends to favour that.... One attends not merely to character types desirable in the abstract...

So one will bear in mind... that ... friendship and respect for human personality really are threatened by hatred, group bias, and anarchic sexuality...that servility, infantilism, and hypocrisy really are evils... that where 'paternalism' on the part of the political community is justified it is ... to be no more than a help to self-correction. ${ }^{37}$

The passage, which in the temper of the age is much more noticeable to the book's average and likely readers than to Fr Fortin, ${ }^{38}$ shows how questionable not only is

${ }^{36}$ NLNR, 216-7 (emphases added).

37 NLNR, 220 (emphasis added).

38 The paragraph begins with overt challenges to the demotic egalitarianism and vulgar disdain for nobility and virtue that Fortin finds pervasive in the book:

So one will bear in mind, on the one hand, that art .... really is better than trash, that culture really is better than ignorance, that.... children really do benefit from a formation that defines paths as well as illuminating horizons.

$N L N R, 220$. This for many readers will have recalled the provocation and ironizing offered at the outset of the book's discussion of distributive justice:

the objective of justice is not equality but the common good, the flourishing of all members of the community, and there is no reason to suppose that this flourishing of all is enhanced by 
his remark about people remaining as they are, but also another set of assessments he makes, presenting the book as "prescinding altogether, as Kant had done, from the distinction between base or selfish and noble or unselfish impulses," and as treating moral virtue as dispensable [596]. In the end, Fortin's presentation of my position ascends to fantasy:

One need not acquire [courage, moderation, and the other moral virtues] in order to enjoy their benefits. Justice is always to my immediate or long-range advantage and the just life is the most pleasant life. At the extreme limit, no one has to worry about ever having to sacrifice himself for the common good. [596].

The real-world NLNR, however, begins and ends its long discussion of the common good with prominent reminders of the moral necessity, sometimes ineluctable, of self-sacrifice:

does not the analysis of morality as reasonableness in self-constitution overlook the fact that moral responsibilities can require one to sacrifice not merely one's selfishness, and one's self-interest, but even, on occasion, oneself?

This chapter undertakes a fuller analysis of the proper relationship between one's own well-being and the well-being of others. It does not complete that analysis.... The question just raised, about the reasonableness of self-sacrifice, and the related question whether the effort to be reasonable is in the end just a pursuit of self-perfection, are questions to be tackled and resolved only in Chapter XIII. ${ }^{39}$

When the issue is resumed, as promised, at the outset of chapter XIII, it is framed as arising both in the context both of friendship, when my friend's well-being "can be secured only by my ruin or destruction," and in the context of responsibilities to family or political community, responsibilities which "reasonably may require self-sacrifice." ${ }^{0}$ The question is kept in view. ${ }^{41}$ The curious inadequacy of Aristotle's attempt to "explain the reasonableness of self-sacrifice for one's friend" is recalled. ${ }^{42}$ The book's explanation "in principle" of "how self-sacrifice in friendship can make sense," along with "our obligation to favour the common good," is finally pointed to in a (very reserved) discussion of divine revelation, first as holding out a divine friend whose favor for the good of one's friends and neighbors "is given knowing fully the true worth and all-explaining point of everything,

treating everyone identically when distributing roles, opportunities, and resources. Thus... what is unjust about large disparities of wealth in a community is not the inequality as such but the fact that (as the inequality suggests) the rich have failed to redistribure that portion of their wealth which could be better used by others for the realization of basic values in their own lives. If redistribution means no more than that more beer is going to be consumed morosely before television sets by the relatively many, and less fine wine consumed by the relatively few at salon concerts by select musicians, then it can scarcely be said to be a demand of justice. But if redistribution means that, at the expense of the wine, etc., more people can be preserved from (non-self-inflicted) illness, educated to the point where genuine self-direction becomes possible for them, defended against the enemies of justice, etc., then such redistribution is a requirement of justice.

$N L N R, 174$.

39 NLNR, 134-5.

40 NLNR, 372.

41 NLNR, 378.

${ }^{42}$ NLNR, 397-8, citing Nicomachean Ethics IX.8: 1169a 18-26. 
of the existence of every person, and of the history of every community." 43 On this basis "we would have a new and pertinent reason for loving [the] common good [of human persons], pertinent even though we could not see how that love would work out in the perspective of all times and places." 44 But the explanation only concludes on the book's original final page of text, with the conclusions drawn from the evocation, via Plato's Laws, of participation in the divine play-in accordance with the divinely-sourced pull of the law (nomos) of practical reasonableness (logismos) — that "in the last analysis ... is the only really serious matter."

In such a "final analysis," in which we seek an understanding going beyond our feelings, the "serious things of life," even atrocious miseries, are really serious only to the extent that they contribute to or are caught up into a good play of the game of the God who creates and favors human good. ${ }^{45}$

Fortin like everyone else would be fully entitled to say that the book's attempt to make full sense of self-sacrifice is of very limited success-or even to try to argue that it simply fails. He was not entitled to suggest that the book in any way teaches that "the just life is the most pleasant life. ... no one has to worry about ever having to sacrifice himself for the common good." 46

\section{Rights, their Logic, and Virtue}

The main thesis of Fortin's review is articulated in its motto, the "little ditty my gang used to sing when I was a kid":

I love Carolina,

I love Angelina, too,

I can't marry both,

So what I gonna do?

His point: one "can't marry both" "rights or freedom on the one hand, and ... virtue, character formation, and the common good on the other." $47 \mathrm{He}$ was fundamentally mistaken, I believe, in his tying of rights to freedom-worse, to Hobbesian freedom from duty-and fundamentally mistaken in contrasting respect for rights (and claims of rights) with virtue, character-formation, common good and natural law (or natural right). One can, and every society and social, political or moral theory should, marry both, for love. And this is not polygamy,

\footnotetext{
${ }^{43} N L N R, 406$.

${ }^{44} N L N R, 407$.

45 NLNR, 410 .

46 Having made the suggestion (596), Fortin then quotes (596-7) from some of the passages that refute it. But he leaves the suggestion in place and compounds it by insinuating that, in $N L N R$, "virtue is not choiceworthy for its own sake" (597). But of course, practical reasonableness, the very source of virtue, is a basic human good, choiceworthy for its own sake like all basic human goods and unlike the others in that it has all of them, and one's participation in them, as precisely its subjectmatter. Still, footnote 11 shows Fortin worrying away at the matter, as one should.

47 The description of the motto and the statement of its meaning are from "The Trouble with Catholic Social Thought," 311.
} 
for they are not two distinct realities but two aspects of - two ways of talking about-one and the same fruitful object of reasonable love and devotion.

The corresponding Straussian bifurcation of history, too, is mistaken, and it pervades Fortin's review. ${ }^{48} N L N R$ rejects the mistake, but not clearly enough. Its discussion should have attended more closely to the Roman-law definition of justice that St. Thomas adopted for his vast treatise on justice, ${ }^{49}$ and to his decision to head up that treatise with a whole article on ius. ${ }^{50}$ For the most correct English translation of that article's subject-matter (ius) is "rights," plural (even though the Latin word is singular). The object of the virtue of justice, and of acts of justice, is rights-in the central sense of that English term, the sense in which its correlative is duties, that is, duties of justice resulting from the directives of natural and, where pertinent, just positive law. These facts, which I believe to be beyond dispute, render the contrasts alleged (albeit variously) by Leo Strauss, Michel Villey and Ernest Fortin simply untenable, both historically and philosophically. It is deeply regrettable that so much scholarly time has been diverted to tracing differences that are in the last analysis almost imaginary.

The mistake takes a particularly muddled form in Fortin's review, because it misunderstands the basic logic of the correlativity of rights (to be treated justly) and duties (of justice) - a correlativity with which Aquinas was working throughout his treatise on justice, and which I spell out in a formally complete way at the beginning of NLNR's chapter on rights. Here is Fortin on that correlativity:

No one [according to $N L N R$ ] has any real duties other than those entailed by the requirements of practical reasonableness ${ }^{51}$ or the need to protect the rights with which he was already gifted prior to his incorporation into civil society. ${ }^{52}$ At most, the central issue of the relation of rights to duties remains blurred [in $N L N R$ ] and the section that deals with it thematically (pp. 205-10) does little to remove the ambiguity. Rights and duties are said to be correlative, as indeed they are-if I have a duty to do something I also have the right to do it, although the converse is not always true-but

48 See Leo Strauss, Natural Right and History (Chicago: University of Chicago Press, 1953). Nonetheless, I profited from the book, especially its chapter IV, "Classic Natural Right," as the markings and annotations to my 1969 copy of it indicate. To take just one example: on p. 127, I marked the passage beginning: "the proper work of man consists in living thoughtfully, in understanding, and in thoughtful action." But $N L N R$ accepts that it cannot presume that human beings have a "proper work," but rather shows this by displaying the good of practical reasonableness, and its intrinsic subject-matter, i.e., the direction of action as a pursuit of this and other basic goods realizable in the life of the acting person and of others-and so forth.

49 S.T. q. 58 a. 1c (justice's firting definition: "the lasting and steady willingness to give to each his/ her right(s)").

50 S.T. II-II q. 57 a. 1 (justice's object: ius). On all this, see my Aquinas, 133-4.

51 Quite so; practical reasonableness is nothing other than my translation of prudentia, the master moral and intellectual virtue, which cannot be found independently of justice (not to mention courage and temperance). It is inconceivable, for St. Thomas as for NLNR, that there could be moral or legal duties not required by the virtue and insights of prudentia.

52 Aquinas's way of referring to duties owed to--and therefore, by entailment, rights possessed bypersons whether or not they have the benefit of living in civil society is to say that there are important respects in which justice is owed to everyone alike (indifferenter) rather than to particular persons or classes of person for reasons particular to them (ex aliqua speciali ratione): see Aquinas, 136. 
this still leaves open the question as to which of the two is the fundamental moral fact. [598-9]

The blurring, like the "leaving open the question," is in Fortin's eye, and has as its direct cause his misunderstanding of the correlativity of rights and duties. ${ }^{53}$ The true correlative of A's duty to B is B's right, ${ }^{54}$ not, as Fortin asserts, A's libertyright to do his duty. And that liberty of $\mathrm{A}$ is so trivial - so merely tautologically entailed by A's duty - as to be of no interest to Aquinas, lawyers ancient or modern, or NLNR. ${ }^{55}$ The true correlative of a one person's duty is another person's right, and vice versa. Justice always concerns what I owe to another-what that other has the right to, from, or as against me. ${ }^{56}$ Everything $N L N R$ says about rights has as its basis the virtue of justice, which is why its chapter on justice (as Fortin fails to note) precedes the chapter on rights.

This makes NLNR's treatment of the "fundamental moral fact" question (rights? or duties?) not blurred but rather transparent:

In short, the modern vocabulary and grammar of rights is a many-faceted instrument for reporting and asserting the requirements or other implications of a relationship of justice from the point of view of the person(s) who benefit(s) from that relationship. It provides a way of talking about "what is just" from a special angle: the viewpoint of the

${ }^{53} \mathrm{He}$ never noticed or shook free from this large mistake. Thus in his most thorough treatment of the issue and the scholarly literature (especially Michel Villey, Richard Tuck and Brian Tierney)Fortin says:

Granted, one cannot conclude from the absence of any explicit distinction between objective and subjective right in their works that the classical philosophers and their medieval disciples would have objected to the notion of subjective rights.... Since rights are already implied in the notion of duty-anyone who has a duty to do something must have the right to do it-there appears to be no reason to dichotomize them. What they represent would be nothing more than two sides of a single coin. If, as was generally assumed in the Middle Ages, there is such a thing as the natural law, one has every reason to speak of the rights to which it gives rise as being themselves natural. (emphasis added)

"On the Presumed Medieval Origin of Individual Rights," in Classical Christianity and the Political Order, 247. In "The Trouble with Catholic Social Thought," 304, likewise:

What once presented itself as first and foremost a doctrine of duties and hence of virtue or dedication to the common good of one's society now takes its bearings, not from what human beings owe to their fellow human beings, but from what they can claim for themselves .... duties are [in modern ethical theory] rooted in pre-existing rights which everyone is obliged in conscience to honor and which must, therefore, be regarded as the primary moral phenomenon.

At first glance, the difference between the two views might be looked upon as one of approach rather than of genuine substance, and the more so as rights and duties are to some extent correlative. If I have a duty to do something, I must also have the right to do it, though the converse need not be true. (emphasis added)

54 In the Hohfeldian terminology adopted and explained carefully on $N L N R, 199-200$, this kind of right - the most fundamental kind-is a claim right: a claim on $A$ that he shall do or forbear in relation to $B$ in some specific respect.

55 The confused interest in this trivial liberty is not original to Fortin; it is to be found in a continental neo-scholastic tradition.

56 S.T. II-II q. 57 a.1c, q. 58 aa. 1c, 2c, q. 80 a. un. c.; $N L N R, 161-2$. 
"other(s)" to whom something (including, inter alia, freedom of choice) is owed or due, and who would be wronged if denied that something. And the contemporary debate shows that there is a strong though not irresistible tendency to specialize that viewpoint still further, so that the peculiar advantage implied (on any view) by any ascription of rights is taken to be the advantage of freedom of action, and/or power to affect the freedom of action of others....

... there is no cause to take sides as between the older and the newer usages, as ways of expressing the implications of justice in a given context. Still less is it appropriate to argue that "as a matter of juristic logic" duty is logically prior to right (or vice versa). But when we come to explain the requirements of justice, which we do by referring to the needs of the common good at its various levels, then we find that there is reason for treating the concept of duty, obligation, or requirement as having a more strategic explanatory role than the concept of rights. The concept of rights is not on that account of less importance or dignity: for the common good is precisely the good of the individuals whose benefit, from fulfilment of duty by others, is their right because required in justice of those others.

\section{As I put it, more tersely but to the same effect, in Aquinas:}

In Aquinas' understanding of justice, rights are as fundamental as duties, and duties as fundamental as rights. We have duties which are not duties of justice, so duty is the wider concept. But when a duty is to another human person, it is a duty of justice, and that other person's right is its very object or point. ${ }^{57}$

Fortin's blunder about the elementary logic of rights and duties is surely a prime source of his mistakes about the history of the rights tradition. For he sees the origin of that tradition in Hobbes. ${ }^{58} \mathrm{I}$ 'm sorry to say that he omits even a hint about the existence of NLNR's exposé, or demolition, of Hobbes's theory of rights:

This [Hobbes's] shift of perspective [towards the perspective of the beneficiary] could be so drastic as to carry right-holders, and their rights, altogether outside

57 Aquinas, 170. That rights are the point or object of justice and its duties (what it owes): Summa Theologiae II-II q. 57 a. 1c, q. 58 a. 1c, q. 60 a. 1c; Aquinas, 133, and see generally ibid., 133-8.

58 Fortin, "The Trouble with Catholic Social Thought," 305:

To the best of my knowledge, the true originator of the rights doctrine is Hobbes, from whom it was taken over by virtually all of the great early modern thinkers, Spinoza, Locke, and Rousseau foremost among them. That doctrine emerged by way of a reaction against premodern thought and signals a radical departure from it.... Its underlying premise is that, contrary to what had been previously assumed, human beings are not intrinsically ordered to a natural end, in the attainment of which they find their happiness or perfection. In Hobbes' own words, "there is no such finis ultimus, utmost aim, nor summum bonum, greatest good, as is spoken of in the books of the old moral philosophers." Human beings are universally actuated, not by a desire for the good of reason, but by an amoral passion, and not the most noble one at that; to wit, the fear of violent death, which constitutes the sole foundation on which a viable theory of justice can be erected. (emphasis added)

In $N L N R$, and for St. Thomas, human beings naturally understand the "good of reason," that is, the good of practical reasonableness, and beyond the fear of violent death they naturally understand the intelligible good of life, in themselves and their fellows; and likewise the other basic intelligible human goods (including friendship). Hence the book's first proposition about Hobbes: "In short, analysis of political community should not be based on a view of what would be reasonable in Hobbes's 'state of nature." NLNR 160. 
the juridical relationship which is fixed by law (moral or posited) and which establishes jus in Aquinas's sense: "that which is just." ${ }^{59}$ For within a few years Hobbes is writing:

...jus, and lex, right and law... ought to be distinguished; because right, consisteth in liberty to do, or to forbear; whereas law, determineth and bindeth to one of them: so that law, and right, differ as much, as obligation, and liberty; which in one and the same matter are inconsistent. ${ }^{60}$

Pushed as far as Hobbes's purposes, this contrast between law and rights deprives the notion of rights of virtually all its normative significance. Hobbes wishes to say that one has most rights when one is in the "state of nature," i.e. a vacuum of law and obligation, since "in such a condition, every man has a right to everything; even to one another's body." 61 But we could just as well say that in such a condition of things, where no persons have any duty not to take anything they want, no one has any rights. ${ }^{62}$

In other words, Hobbes's theory of rights is rationally ineligible, an outrageous muddle: the state of nature is a condition in which there are not only no legal rights but also no human or natural rights. Hobbes's confused prioritizing of bare liberty, unprotected by any claim-rights, had some influence on other voluntarist thinkers such as Locke and Pufendorf. But their deployment of a partially Hobbesian, liberty-prioritizing logic of rights was watered down by their simultaneous, partly incoherent, but real adherence to main elements of the classical and Christian conception of rights: as correlatives of duties defined by the same natural law as provides the propositional content of the arduous virtues of

59 [By "Aquinas's sense," NLNR meant the sense primary in Aquinas's official list of meanings of "ius": see 206 and 207. It is in relation to this that $N L N R, 206-8$ talks about a "shift of perspective" and a watershed." On all this the Postscript to NLNR now comments (465):

...the discussion of the history of the word 'jus' in the present section fails to notice how Aquinas's definition of justice, and his prior identification of $j u$ as the very object (proximate goal and rationale) of justice, entail that-though it does not clearly appear from his formal account of the senses of 'jus'-in his view, jus (a right) is something that belongs to the subjects of law or moral relationships, and therefore has the essential characteristic of a subjective right. This being so, the 'watershed' spoken of in the first full paragraph on p. 206 must be regarded as much more a matter of appearance and idiom than of conceptual, let alone political or philosophical, substance. Evidence for this conclusion is in Aquinas 133-8; and [Finnis, "Aquinas on jus and Hart on Rights: A Response [to Tierney]", Review of Politics 64 (2002) 407-10], (to which Tierney's reply, in the same issue of the Review of Politics, seems ineffective, because he misunderstands the modern concept of rights). As to the meaning of 'jus' in Roman and mediaeval canon law (see the second endnote on [NLNR] 228), Tierney's rapprochement with Villey in 2002 is the more surprising in light of his refutation of Villey, in Tierney, 'Villey, Ockham and the Origin of Individual Rights', J. Witte and F. Alexander (eds), The Weightier Matters of the Law (Atlanta, Scholars Press: 1988), 1-31. The willingness of a scholar as historically informed and linguistically sensitive as Honoré to attribute thoughts about human rights to classical Roman jurists such as Ulpian is important evidence against the strong watershed theory.]

${ }^{60}$ Leviathan (1651), ch. xiv. Thus for Hobbes as for Hohfeld, liberty is simply the negation of duty, and this "liberry-right" is the only right Hobbes has in mind.

${ }^{61}$ Leviathan (1651) ch. xiv.

${ }^{62}$ NLNR, 208 (emphasis in the original), which adds:

The fact that we could well say this shows that the ordinary modern idiom of 'rights' does not follow Hobbes all the way to his contrast between law and rights. Nor did Locke or Pufendorf; yet they did adopt his stipulation that 'a right' (jus) is paradigmatically a liberty. 
prudentia and justice. Hobbes cannot conceivably be the originator of the modern sense of rights, as one finds them stated in the Universal Declaration of Human Rights 1948 or any of its countless derivatives and antecedents.

Since the matter is so important for an understanding of political thought, old and current-not least Catholic political thought-it is worth going through Fortin's summary of his position, ${ }^{63}$ commenting briefly by interjection into the continuous passage setting it out:

It is significant that the notion of universal human rights, understood as rights that inhere in each human being by reason of the fact that he or she is a human being, does not occur anywhere in premodern thought and, until very recent times, only sparingly in Roman Catholic thought.

Not so. Just as a notion of the Trinity occurs in the New Testament ${ }^{64}$ without the term "Trinity" or any verbal equivalent, so the notion of universal human rights has been present in "pre-modern" and "Roman Catholic" thought, expressed in statements to the effect that all human beings are protected by the duties of justice, duties that are owed to, for example, the new-born child who might by custom be left to die on the mountainside, or the servant-girl or -boy who might by custom be taken for sex, or the passing stranger who might by some custom be robbed at least of his luxury goods. ${ }^{65}$

The Bible itself, which shares to some degree the perspective of classical philosophy on this point, does not promulgate a Bill of Rights, of which it knows nothing; instead, it issues a set of commandments.

Yes, and these are the precepts of which Aquinas says (i) that they apply to every human being alike (communiter omnibus and indifferenter ${ }^{66}$ or inquantum est hom $o^{67}$ ), and (ii) that, being precepts of justice, they have as their very object the rights of those-everyone-to whom justice is owed. ${ }^{68}$

For centuries, the corner-stone of Catholic moral theology was not the natural or human rights doctrine but something quite different, called the natural law.

No: natural law, like the set of duties it picks out and directs us to-not least but not exclusively duties to others with corresponding rights-remains the cornerstone of Catholic moral theology. The fact that that theology is now articulated in terms of rights as well as duties changes its propositional content not at all, but (when rightly understood) clarifies both its bases and its implications. Natural law stands to natural rights, not as something "quite different," but as premises stand to entailments.

63 "The Trouble with Catholic Social Thought," 304-5. My criticisms of this passage do not detract from my agreement with a number of the severe criticisms Fortin in that paper makes of the methodology of various episcopal (not to mention papal) "social teaching" documents.

${ }^{64}$ E.g., Matthew 28: 19.

65 See, e.g., from the late first century AD, the Didache II.2, and the Epistle of Barnabas XIX.4 and 5. Each presents the negative duty (not to choose such types of act) within the positive duty to follow the Way of life and light.

66 S.T. II-II q. 122 a. 6 "to everyone in common," "without distinction"; Aquinas, 136-7.

67 S.T. II-II q. 57 a. 4 ad 2; Aquinas, 171.

${ }^{68}$ S.T. II-II q. 57 a 1c; q. 58 a. 1c; q. 60 a. 1c; Aquinas, 133. 
Rights, to the extent that they were mentioned at least by implication, were contingent on the fulfillment of prior duties.

Not true. It is the repeated teaching of St. Thomas, with no sense of innovation, that children incapable of fulfilling prior duties had rights, including rights against their parents, who wronged them-implicitly, violated their rights - when they violated parental duties of care and respect, and the child's entitlement not to be obliged to do wicked things and to make his or her own choice of life-vocation and spouse. ${ }^{69}$

Far from being absolute or inalienable, they could be forfeited and were so forfeited by the individual who failed to abide by the law that guaranteed them.

The rights that are truly absolute today were absolute, and for the most part clearly recognized as absolute, in classical Christian doctrine and theology. Fortin errs fundamentally when he says that "the rights whose defense $[N L N R]$ takes up are still perceived as absolute or unconditional rights" [596] and speaks of "Finnis's teaching regarding the absolute inviolability of all basic human rights." [604]. ${ }^{70}$ The term "basic rights" did not appear in the book Fortin was reviewing, and the rights which $N L N R$ defends as natural include many that cannot sensibly be called absolute but rather are contingent, for their specification (their specific application), on other changeable aspects of the common good of the communities in which respect for them comes in issue. ${ }^{71}$ The absolute rights that $N L N R$ proposes and defends in the short section entitled "Absolute Human Rights," at the end of the chapter on rights, are few in number (though of strategic signifcance for law, politics and individual life).

Finally, then, the passage I have been quoting from Fortin concludes:

Simply stated, what the church taught and tried to inculcate was an ethic of virtue as distinct from an ethic of rights.

But although the Church was not unreasonably hesitant to adopt an idiom that had been so prominently abused by bitterly anti-Catholic and philosophically (and theologically) very confused thinkers, such as Hobbes and Locke and the swarm of revolutionary propagandists who promulgated the "rights of man and citizen," it was never the case that an ethic of virtue need be in any way, even slightly, opposed to a reasonable ethic of rights. For it is as true now as it was in Aristotle's time ${ }^{72}$ or

${ }^{69}$ See Aquinas, 11, 18,169,171, 172n, 174-5 and the texts of St. Thomas there cited.

70 The same astonishing mistake is made by Edward Goerner in his extensive remarks about NLNR in "Letter and Spirit: The Political Ethics of the Rule of Law Versus the Political Ethics of the Rule of the Virtuous," Review of Politics 45 (1983): 553-75, at 561 :

[according to $N L N R$ ] questions about what is just or right are always and only to be answered by showing that a proposed course of action is logically consistent with the body of propositions stating the universally applicable rules or laws concerning rights. . . the rights which are thus laid down and their correlative duties are, and must be, to use Finnis's terms, "exceptionless" and "absolute."

71 See NLNR, ch. VIII.4 (Rights and the Common Good), VIII.5 (The Specification of Rights). The key passage regarding specification is quoted above at n. 37 .

72 See Fred. D. Miller, Nature, Justice and Rights in Aristotle's "Politics" (New York: Oxford University Press, 1995), just in so far as it argues that Aristotle had "locutions for rights" 
Gaius's ${ }^{73}$ or Aquinas's or Pius VI's, Leo XIII's or John XXIII's that the philosophically or theologically defensible doctrine of virtue includes a doctrine of justice that in turn, given the resources of modern European languages, can most authentically be set out in terms of rights (which entail their correlative duties). ${ }^{74}$

\section{Rights and Modernity}

The more or less Straussian view of political history that Fortin seems to have accepted $^{75}$ is, I believe, historically very flawed in so far as it views political or political-theoretical history as divided-by a caesura, if not a watershed-between a pre-modern age, innocent of rights (or at least of human rights), and a modern age, insistent on rights (and pro tanto careless of virtue and common good). For such matters do not turn on a word or a concept. To go no further than Aristotle's Politics:

In democracies of ... the type which is regarded as being peculiarly democratic... [there is] a false conception of liberty ... of individuals. The democrat starts by assuming that justice consists in equality... he ends with the view that "liberty and equality" consist in "doing what one likes"... for any end one chances to desire. ${ }^{76}$

A more real caesura or watershed is the emergence and working through of the Christian conception of radical equality of all human beings, in humanity and destiny. This would have worked its leaven or ferment regardless of the emergence of a vocabulary of rights.

Conversely, the irresponsibility of many revolutionary proclamations of rights, and today the injustice and destructiveness of "the woman's right to choose [to

(93) even though "though no single Greek word corresponds to the single modern term "right" (196).

${ }_{73}$ Gaius in the second century AD taught that neither state law nor communal convention can do away with natural rights. See Digest 43.18.2: civilis ratio corrumpere naturalia iura non potest. Likewise Gaius, Institutes II. 65.

${ }^{74}$ Curiously, perhaps, Fortin's 1988 article on Carholic social thought concludes:

My point, and it is the only one I have tried to make, is that the bishops may have confused some of their readers by using language that looks in two different directions at once: that of rights or freedom on the one hand, and of virtue, character formation, and the common good on the other. They would certainly be ill-advised to give up their vigorous defense of rights, especially since the pseudomorphic collapse of Neo-Thomism in the wake of Vatican II has left them without any alternative on which to fall back; but they have yet to tell us, or tell us more clearly, how the two ends are supposed to meet. Reading their letters reminded me of a little ditty my gang used to sing when I was a kid:

I love Carolina....

75 The Schedule and reading list for Fortin's graduate/undergraduate course "Natural Law" (Th. 580) at Boston College in Spring 1978 assigned Strauss, Natural Right and History for eight of the 14 classes, in six of these as the sole "recommended" secondary source.

76 Politics V.ix sec. 16: 1310a (trans. Ernest Barker). Pol. VI.ii secs. 5-5: $1317 \mathrm{~b}$ explains that equality in the "democratic" conception of it is arithmetical, not proportionate to desert or merit-though restricted to citizens, not slaves-and on that understanding is "a general system of liberty based on equality." 
kill her child]" or the follies and injustice of "gay rights," "the right to private life," or "the right to migrate," could and I believe would have emerged when they did, regardless of theories of rights. The pre-modern vocabulary of liberty and equality available to the sophists and demagogues known to Plato, Thucydides and Aristotle could today as then-and just by itself-serve as matrix for demands promoting the vices of lust, cowardice and injustice (and for sophisms rationalizing these violations of prudentia) just as well as any modern idiom of rights can serve.

\section{V. "Only Analogically Law"}

Fortin's review most particularly obscured potential readers' view of the book with his claim that for $N L N R$ "the natural law as Thomas understands it. ... is only 'analogically law' (p. 280)" [605]. Fortin links this with claims about NLNR having a purpose of "stripping" natural law doctrine of any element of coercion or sanction. I will take the two issues separately.

Fortin's purported quotation from NLNR, 280 is highly misleading, and has misled a good many. The sentence from which he quoted just two words states that "Natural law'... is only analogically law, in relation to my present focal use of the term: that is why the term has been avoided in this chapter"law as it is found in "the central case of law and legal system... of a complete community purporting to have authority to provide comprehensive and supreme direction for human behavior in that community, and to grant legal validity to all other normative arrangements affecting the members of that community" (260, opening words of the chapter). The section from which Fortin was quoting is entitled "A Definition of Law," and begins with the book's notorious sixteen-line definition, which includes, as one element among many, "buttressed by sanctions in accordance with the rule-guided stipulations of adjudicative institutions."77 That element is only one of a number that make the definition inapplicable, in any non-analogical way, to natural law. And the snippet quoted by Fortin comes near the end of a paragraph the whole burden of which is that what is central, and what analogical, depends on one's theoretical purposes. What is centrally law for physicists is only analogically or metaphorically law for jurists. Ignoring this, Fortin eventually has me saying that "the natural law is ... a mere lex indicans," not "a lex praecipiens, enjoining or forbidding certain actions not only as intrinsically good or bad but as meritorious or demeritorious." [607]

Once again, Fortin treats "meritorious and demeritorious" as if these predicates turned on sanctions, and I will return to this in a moment. The point to make just now is that throughout $N L N R$, natural law is treated as genuine law, not merely "indicating" what is "intrinsically good or bad," but rather requiring conduct as obligatory, ${ }^{78}$ such that non-compliance is not merely bad but wrongful and

78 And this includes obligations in respect of one's own self-regarding conduct: NLNR, 298. But it is a devastating error for Fortin to think that, for $N L N R$, "natural law. ... merely points to what one must do or avoid in order to fulfill oneself." [605]. The fulfilment to which natural law points is, as I 
culpable and in many cases deserving or meriting of punishment for the sake of retributive justice. For $N L N R$, natural law, both in itself and for Aquinas, is praecipiens, imperative though not by reason of a superior's command still less by reason of sanctions imposed by a commander. ${ }^{79}$ (Pace Fortin, NLNR does clearly affirm the existence of "natural sanctions" (poena naturae).) $)^{80} \mathrm{No}$, the reason why natural law has law's quality of being preceptive, imperative or mandatory, obligatory, compelling in conscience, and so forth, is because it rationally picks out and directs us to common good in the measure prescribed by the requirements of practical reasonableness. Following the precepts of the natural law is what it takes to be practically reasonable, whatever the personal cost of doing so and being so.

And that is not a matter of subjection to divine sanctions. Fortin tries to make St. Thomas hold that natural law is law, obligatory, because of divine "enforcement," God's threatened sanctions. But the texts he cites ${ }^{81}$ relate-quite plainly, when they are read through beyond the snippets he selects from them-to human law or revealed divine law, each of which Aquinas clearly distinguishes from natural law, notwithstanding that the content of human and divine law, respectively, should and does overlap substantially with the content of natural law. Coerciveness is simply no part of Aquinas's careful definition ${ }^{82}$ of law, a defining precisely for the purpose of showing how and why natural law, divine revealed

make clearer from 1983 onwards, integral buman fulfilment - that is, the fulfilment of all human persons and communities, in which one's own fulfilment has no priority of value but only of responsibility: $N L N R, 419-20$. Equally devastating as a misreading is Fortin's claim that, according to $N L N R$, the term "natural law" is associated with the notion of obligatoriness only by a misunderstanding perpetrated by Vazquez and Suarez and prevalent today [606]. This ignores wide tracts of the book, for example, the formal treatment of obligation in chapter XI, which identifies ( $N L N R$, 303) the key move in explaining obligation (e.g., the moral obligation of promises) as the ascent to the level at which the explanation incorporates

what we have previously laboured to explain: that one (everyone) has reason to value the common good-the well-being alike of oneself and of one's associares and potencial associates in community, and the ensemble of conditions and ways of effecting that well-being-whether out of friendship as such, or out of an impartial recognition that human goods are as much realized by the participation in them of other persons as by one's own (see VI.4, VI.6, VII.2).

And it is this connection to common good that can, and often does, make moral obligations burdensome for the one who has them (see 307) or even (as Fortin remembers elsewhere in the review but not here) catastrophically burdensome (224-6) and in need of some further explanation (see at nn. 39-42 above).

${ }^{79} N L N R, 44-6,54,122,259,338-42,425$, etc.

80 NLNR, 380, 411.

81 S.T. I-II q. 96 a. 5 entirely concerns human (positive) law, not natural law as such; the ad $3 \mathrm{~m}$, for example, holds that the ruler who is not subject to the law's vis coactiva is nonetheless subject to its vis directiva (which is far more than mere lex indicans, and ought to be obeyed by the ruler unless he happens to have power to dispense from it); I-II q. 100 a. 9 c repeatedly says it concerns lex divina et lex humana.

82 ST I-II q. 90 a. 4c: an ordinance (prescription) of reason for the common good of a community, promulgated by the person or body responsible for looking after that community. Aquinas, 256, commenting on this, says:

Aquinas takes an early opportunity to supplement his definition by stating that it is characteristic of law \{de ratione legis\} that it be coercive (threatening force against violators). [fn. I-II q. 90 a. 3 ad 3, q. 96 a. 5 c. Both passages also link law's coerciveness with its public character...] 
positive law, and human positive law (not to mention the eternal law of Providence) are, each in its own significantly differing way, law. No need to dwell on this part of Fortin's review, which runs into the sands, as he virtually admits when trying to account for the absence of natural law from the Summa contra Gentiles. St. Thomas holds what St. Paul holds in Romans 2: 12-16: that even those human beings who have never heard, or heard of, the divine law, or of God, can know "by nature" what the divine law requires; what they know is precisely the natural law, which accuses them in their consciences when they violate it, even though they are unaware that God too will in due time accuse them of such violations. Yes, revelation discloses that the natural law is upheld by divine sanctions (and corresponds in its content to much of the divine law), but the sanctions (and the overlap with divine law) are not what make it law or binding. ${ }^{83}$

In a curious aftermath of the review of $N L N R$, Fortin and Edward Goerner engaged in an exchange "on the naturalness and lawfulness of the natural law." Goerner's views on Aquinas were even more skewed than Fortin's were by Straussian misreadings: he saw Aquinas as a practicer of veiled, esoteric writing to conceal and convey an elitist conception of morality as comprising unnuanced norms (of law, lex) for the many but nuanced, equitable norms (of right, ius) for the few-so that "Thomas's moral and political doctrine is not fundamentally a natural law teaching at all, and that in his teaching the morality of natural law is crucially different from (and subordinate to) the morality of natural virtue." ${ }^{84} \mathrm{He}$ also shared Fortin's mistakes ${ }^{85}$ about the necessarily sanctioned character of (Aquinas's) natural law, which according to him "leads men to obedience by fear of punishment." 86 But the point is that the debate between them elicited from Fortin the statement or admission that he himself had no natural law

Here, as generally though not universally, throughout qq. 90-105, Aquinas quietly treats human positive law as the central case of law and focal meaning of lex and (in one of its two main senses) ius. ${ }_{83}$ Fortin had worked intensively on natural law theory not many years before his review of NLNR, and had concluded to-or perhaps started from-the position that natural law, as distinct from (or contrasted with) natural right, is "a legally sanctioned order extending to the whole of human life," a "universal law whose injunctions can never be infringed with impunity"; to believe in natural law is to believe "that crime never pays and that in the end the only people who are happy are the ones who deserve to be happy," by virtue of "a law of the cosmos certifying that justice will necessarily prevail in human affairs," in "a morally lawful universe in which all evils are eventually set straight": "Augustine, Thomas Aquinas, and the Problem of Natural Law," in Classical Christianity and the Political Order, 199-222, at 201. Having invented this idea of natural law, Fortin of course had difficulty finding anyone, ever, who has defended a natural law theory; I know of no-one.

${ }^{84}$ See E.A. Goerner, "Thomistic Natural Right: the Good Man's View of Thomistic Natural Law," Political Theory 11 (1983): 393-418, at 393-4; see also his "On Thomistic Natural Law: The Bad Man's View of Thomistic Natural Right," Political Theory 7 (1979): 101-22. A brief refutation of the main thesis: Aquinas, 134. Some passages where Aquinas uses ius and lex together and interchangeably: S.T. II-II q. 85 a. 1, q. 187, a. 3 ad 1. Goerner was a teacher/professor of political theory at Notre Dame for fifty years from 1960.

${ }^{85}$ Goerner, "Thomistic Natural Right," cited other texts, however, though no more relevantly than Fortin: in S. T. I-II q. 92 a. 2 c and ad $3 \& 4$ and q. 100 a. 1 c, not to mention q. 90 a. 3 ad 2, natural law is not under consideration when Aquinas is speaking of vis coactiva (coercive force) or metus poenae (fear of penalty).

86 "Thomistic Natural Right," 395 (in the course of expounding "the conventional view"); "Thomistic Natural Law," 111: 
theory. ${ }^{87}$ This helps explain his somewhat shaky grip on issues such as obligation, and his collapse of Aquinas's resolutely reason-, good-, and end-centered account of law, natural law, and much else, into voluntarism, primacy of will, and even dependence on sanctions, to explain what makes law law. $N L N R$ is from beginning to end a critique of such a flight from the normativity, the imperative preceptiveness, of reasons.

\section{Exceptionless Moral Norms: For and (Fortin) Against}

Fortin's remarks [604] in (not quite fully assertive) defense of the use of torture (with no suggestion of inherent limits) ${ }^{88}$ in exceptional, emergency circumstances constitute his response to a theme that in NLNR goes wider and includes other kinds of case, notably (so far as concerns the book's rhetorical energy) the killing of innocent, non-combatant hostages in war, and the deterrent threat to do so maintained by "every government that has the physical capacity to make its threats credible..." 89 NLNR carries through its defense of exceptionless moral norms, commenced in chapter IV.7 and crystallized in chapter VIII.7's discussion and list of half-a-dozen absolute human rights. The tone and content of Fr. Fortin's comment are strongly reminiscent of the pungent passage in the exact center of Strauss, Natural Right and History, pages 160 to 162 of that 323-page book, in the core of his discussion of the central type among the "three types of classic natural right teachings." As I say in my 1990 essay on it:

this passage of Strauss's is to be taken as a studied defense of the "total war" policy of the Allies in the war which ended only four years before Strauss's lectures-a policy extended into western post-war security policy. Nuclear deterrence treats the "extreme situation" as, in a decisive aspect, the simply "normal." 90

That last sentence is my comment, not Strauss's admission. As I also note there, Strauss's discussion (of which I quoted a substantial central part with which readers could profitably compare Fortin's paragraph on torture),

the natural law, like all law (cf., I-II q. 92, art. 2, ad 3), is an external constraint effective through fear of punishment whereas natural virtue is an internal principle effective by love of the good.

...

... that is to say, a full understanding of Thomas's natural ethics must rest on his teaching about natural virtue rather than about natural law.

87 "He [Goerner] may even wish to develop his own natural law theory, as I hope he will. Having no such theory myself, I was merely content with trying to make sense of Thomas's statements on the subject." Fortin, "A Reply," Review of Politics 45 (1983): 448.

${ }^{88}$ On what really is torture, exceptionlessly excluded from conscientious choice by natural law, see Patrick Lee, "Interrogational Torture," American Journal of Jurisprudence 51 (2006): 131-47; CEJFI, 102.

$89 N L N R, 224$, where both content of the threat and the motivations for making it are said to be the same (albeit not yet executed) "as old-fashioned torturers seeking to change their victim's mind or the minds of those next in line for the torture."

${ }^{0}$ CEJF I, essay 12 ("Moral Absolutes in Aristotle and Aquinas"), 187-98, at 188. Cf. Fortin [604]: "Finnis's principle [prohibiting recourse to torture under any circumstances], noble as it may be, is more readily applicable to normal than to emergency situations." 
anticipated, remarkably, the main themes of the critique which, in the following forty years, was to be directed by certain Catholics ${ }^{1}$ against the Christian moral teachings which Aquinas helped transmit. These themes: Moral judgment has its truth only in and for "particular situations;" in situations of "conflict" one should decide by reference to a particular "common good" which relativizes the principles of justice and suspends certain "rules of natural right;" "there is not a single [moral] rule... which is not subject to exception;" and what ultimately matters, in the exceptional situations, is not what one does but that one does it with an attitude, for example of "reluctance." Whatever Strauss's success in articulating the spirit of "the classics," he certainly conveyed some characteristic elements of the spirit of the mid-and late twentieth century.

But even if one frees oneself as best one can from the spirit of the age, and from the spirit of ancient paganisms, philosophical or otherwise, and from every illusion about our ability to assess and evaluate by reason the overall likely consequences of alternative options available to us (including, not least, the reflexive consequences for the character of all who choose or approve an option), it remains that agonizing predicaments - of the kind Fortin gestures towards as emergencies, and as potentially tragic - are real, and really test every philosophical moral judgment that seeks to be principled, truly reasonable, more than a sophisticated rationalization. I think Fortin was fair to imply that $N L N R$ takes too few brushstrokes to paint this predicament in all its darkness, and in hinting at heaven as resolution of the divine game ${ }^{92}$ should also have hinted at hell-as Fundamentals of Ethics's last chapter was soon to do (with more than hints). But the real bearing of Christian revelation on these matters is richer and more extensive than any traditional concepts of the ultimate last things, proposing as it does, a kind of continuity-intelligible though entirely dependent on miraculous divine action, gratuitous but promised in revelation-between the building up of persons and their communities in morally good choices (and "works") and eternal life in the completed Kingdom. ${ }^{93}$ NLNR attempted no more than to open a pathway towards a point - call it a way-station-from which a reader might trek on, by another way and not without labor or grace, to the vantage point of true revelation, from which point concepts or realities such as the Kingdom of God and its completion and its conditions of citizenship can become visible, and enticing. A political theory worthy of the name of philosophy has to venture towards that way-station and be able to indicate how it can reasonably be judged to be only a way-station and starting point for something more and, in its own way, better. ${ }^{94}$

${ }^{1}$ [Notably, those currents of proportionalist and other thought identified more or less adequately in the encyclical of John Paul II, Veritatis Splendor (1993) as opposed to the doctrine that there are moral truths of moral law that exceptionlessly exclude certain types of act as intrinsically wrong and never to be chosen, whatever the circumstances: for the exact formulation of the doctrine: see secs. 76, 78,80 . On the origins of this movement of thought among Catholic theologians, see Finnis, Moral Absolutes: Tradition, Revision, and Truth (Washington DC: Catholic University of America Press, 1991), ch. IV.]

${ }_{92} N L N R, 410$.

${ }^{33}$ CEJF V: 119, 228, 254, 366, 371.

${ }^{94}$ But that is not to say that every book that takes its place among ventures both philosophical and Catholic needs to attempt to give such an indication, let alone an explanation of the indication. And $N L N R$, even in its Postscript, abstains - for the reasons suggested in part I above-from such an attempt, leaving that to other works such as, inter alia, the 1999 essay cited at $\mathrm{n} .8$ above. 
